OPEN ACCESS

Edited by:

Ali Derakhshan,

Golestan University, Iran

Reviewed by:

Reza Bagheri Nevisi,

University of Qom, Iran

Yanzhi Meng,

Xinxiang Medical University, China

*Correspondence:

Jingsheng Zhang

xyshishui@126.com

Specialty section:

This article was submitted to Educational Psychology, a section of the journal

Frontiers in Psychology

Received: 31 December 2021

Accepted: 18 January 2022

Published: 11 February 2022

Citation:

Zhang J (2022) The Impact of Positive Mood and Future Outlook on

English as a Foreign Language Students' Academic Self-Concept.

Front. Psychol. 13:846422.

doi: 10.3389/fpsyg.2022.846422

\section{The Impact of Positive Mood and Future Outlook on English as a Foreign Language Students' Academic Self-Concept}

\author{
Jingsheng Zhang* \\ School of Foreign Languages, Xinyang College, Xinyang, China
}

Due to the fact that English as a foreign language (EFL) students' academic self-concept is of high importance for their academic motivation, academic achievement, and L2 success, many investigations have been done to uncover the personal and interpersonal factors that may contribute to students' academic self-concept. Yet, the emotional and psychological factors have rarely been studied. In addition, no empirical and review study has been carried out to probe into the impact of positive mood and future outlook on EFL students' academic self-concept. Accordingly, the current review study seeks to illustrate the effects of positive mood and future outlook on EFL students' academic self-concept. Building upon the principles of positive psychology (PP), the favorable effects of positive mood and future outlook on EFL students' academic self-concept were thoroughly explained. The educational implications and suggestions for future research are also highlighted.

Keywords: positive mood, future outlook, academic self-concept, EFL students, positive psychology

\section{INTRODUCTION}

Students' thoughts and perceptions of themselves and their academic capabilities have gained momentum in the educational domain due to the undeniable function they serve in understanding what drives them to act or abstain from acting in classroom contexts (Erten and Burden, 2014). The personal thoughts and perceptions of students about themselves and their academic abilities are called "student academic self-concept" (De Fraine et al., 2007). According to Marsh and Martin (2011, p. 60), student academic self-concept refers to "students' personal beliefs of their academic abilities and skills that are developed through experience with and interpreting the learning environment." It is suggested that how individual students conceive themselves and their abilities can largely affect their academic motivation (Emmanuel et al., 2014; Seaton et al., 2014), academic growth (Zhang et al., 2018), academic achievement (McInerney et al., 2012; Chao et al., 2019), and success (Prince and Nurius, 2014; Lohbeck et al., 2017). Accordingly, determining factors that may positively affect students' academic self-concept seems essential. To respond to this necessity, several researchers have examined the impact of various personal (e.g., personality, sense of belonging) and interpersonal factors (e.g., teacher-student rapport, teacher support) on students' academic self-concept (Curtin et al., 2013; Kim and Sax, 2014; McFarland et al., 2016; Trautwein and Möller, 2016; Cooper et al., 2018; Ma et al., 2021, to 
cite a few). Nevertheless, the influence of emotional and psychological factors such as positive mood and future outlook has remained elusive.

Generally, mood is a transient emotional state that is limited to a particular time and situation (Jeon, 1990). Positive mood also refers to "one's mental state and feelings where she/he feels more confident, optimistic, and unconstrained" (Febrilia and Warokka, 2014, p. 3). As Brand et al. (2007) noted, students with positive moods are more likely to achieve academic success. Similarly, Cianci and Bierstaker (2009) also submitted that students' positive mood enables them to achieve higher learning outcomes. Following such statements, some studies have been conducted on positive mood and its educational consequences (e.g., Lount, 2010; Akbari Chermahini and Hommel, 2012; Febrilia and Warokka, 2014; Grol and Raedt, 2014). As evidenced by the results of these studies, students' positive mood is closely related to their increased achievement, higher learning outcomes, and success.

Future outlook as another influential factor in students' academic self-concept pertains to one's beliefs and expectations regarding the formation of future events (Nuttin, 2014). As Seginer (2009) maintained, students' ideas of how well they will perform on forthcoming learning activities can favorably influence their academic performance. Schoon (2012) also asserted that students who firmly believe in a bright future are more likely to experience success in different aspects of their lives. Considering these assertions, several investigations have been conducted to determine the factors contributing to students' positive future outlooks (Shane and Heckhausen, 2016; Schoon and Mortimer, 2017; Pax, 2020).

With regard to the principles of positive psychology, positive mental state and feelings that language learners experience in classroom contexts (i.e., positive mood) and the positive beliefs they possess about their future (i.e., future outlook) may favorably influence their academic behaviors (Dewaele et al., 2019; Li et al., 2020; Wang et al., 2021). Yet, not much attention has been paid to the impact of positive mood and future outlook on English as a foreign language (EFL/ESL) students' academic behaviors. Moreover, to the best of the author's knowledge, no empirical and review study has been conducted to delve into the impact of positive mood and future outlook on EFL students' academic self-concept. To address these lacunas, the current review study seeks to examine the effects of positive mood and future outlook on EFL students' academic self-concept.

\section{REVIEW OF LITERATURE}

\section{Positive Mood}

Mood in a general sense pertains to "one's feeling state" or how an individual feels when executing a particular activity (Fiedler et al., 2003). While there is a debate on how to categorize different types of moods (Djamasbi et al., 2010), in the realm of research, moods are typically grouped under three broad categories: negative, neutral, and positive (Venkatesh and Speier, 1999). The third category (i.e., positive mood), which is the focus of the present study, has been characterized as "one's mental state and feelings where she/he feels more confident, optimistic, and unconstrained" (Febrilia and Warokka, 2014 , p. 3). The concept of positive mood theoretically dates back to "positive mood theory" (Isen, 2008). Relying on this theory, being in a good mood can have a considerable impact on how individuals perceive themselves and others. It can also affect how one thinks about his/her own capabilities, abilities, and skills (Fredrickson, 2003; Djamasbi et al., 2009).

So far, some researchers have studied positive mood and its association with a range of educational factors (e.g., Akbari Chermahini and Hommel, 2012; Febrilia and Warokka, 2014; Grol and Raedt, 2014; Holman and Niven, 2019; Mackie and Worth, 2020; Wang and Guan, 2020). Febrilia and Warokka (2014), for instance, have probed into the impact of positive mood on students' achievement and academic performance. To do so, three relevant questionnaires were given to 106 university students. The participants' answers to the close-ended questionnaires were analyzed using structural equation modeling. The results of the analysis evinced that a positive mood has a favorable influence on both students' achievement and academic performance. As another instance, Holman and Niven (2019) have examined the role of positive mood in students' task performance. To gather the required data, two valid measures of the variables were administered to 78 college students. The inspection of students' answers revealed that positive mood as an emotional trait can serve a facilitative function in improving students' task performance.

\section{Future Outlook}

Future outlook pertains to one's beliefs and expectations regarding the formation of future events (Nuttin, 2014). Future outlook as a psychological construct encompasses two distinct components, namely future expectancy and future worry (Wigfield and Eccles, 2001). Future expectancy as the first component deals with "how one expects they will perform on upcoming tasks" (Eccles, 1983, p. 76). Future worry, on the other hand, relates to "the cognitive activity of worrying about the future" (Eccles and Wigfield, 1995, p. 216). In light of the expectancy-value theory, Wigfield et al. (2017) submitted that students' beliefs and expectations about their academic future can affect their learning outcomes. To them, more positive beliefs and expectations will culminate in more desirable learning outcomes. Accordingly, one can conclude that students' learning outcomes are subjected to their future outlook. Due to the importance of future outlook, some investigations have been carried out into this construct to uncover its educational consequences. A review of the existing literature indicates that students' future outlook can drastically influence their academic achievement (Shane and Heckhausen, 2016; Schoon and Mortimer, 2017).

\section{Student Academic Self-Concept}

Self-concept generally refers to a set of beliefs, ideas, and dispositions people maintain and describe themselves (Drew and Watkins, 1997). Further referred to this concept as a 
multi-faceted construct that represents individuals' appraisal of their own abilities and skills. Extending this definition to the educational domain, Mercer (2011) defined student academic self-concept as individual students' viewpoints regarding their academic capabilities and learning skills. As Mercer (2009) mentioned, student self-concept is a "dynamic situational construct" that may change over the course of life. Consistent with ideas of Mercer (2009), Weiner (2010) also submitted that students' beliefs about themselves and their capabilities are alterable. To illustrate the value of student academic self-concept, Dörnyei (2009) maintained that how students see themselves can greatly influence their academic behaviors. Further, Huang (2011) also asserted that students' self-concept can predict their success in educational contexts. More recently, Möller et al. (2020) stated that students' academic self-concept is tied with their increased achievement. That is, any improvement in students' academic self-concept may culminate in higher learning outcomes.

To date, several inquiries have been conducted on student academic self-concept, its antecedents (e.g., Franklin et al., 2017; Wolff et al., 2018; Yeboah et al., 2018; Kulakow, 2020; Biyikl, 2021, to cite a few), and its possible consequences (e.g., Chen et al., 2015; Amiryousefi and Mirkhani, 2019; Colmar et al., 2019; Ehm et al., 2019; Asadzadeh Maleki et al., 2021; Haktanir et al., 2021, to cite a few). Concerning the antecedents of student academic self-concept, Franklin et al. (2017), for instance, explored the factors predicting college students' academic self-concept. To do so, 132 African American students were invited to take part in some interview sessions. The analysis of students' answers to the interview questions demonstrated that student-professor interactions and grade point average are two significant predictors of students' academic self-concept. By the same token, Yeboah et al. (2018) probed into the factors that may significantly promote high school students' self-concept. To this end, 40 American students were interviewed in order to identify the determinants of students' self-concept. The findings revealed that collaborative learning activities, teacher-student rapport, student-student interactions, and parental support can positively predict students' academic self-concept.

To determine the consequences of student self-concept, Chen et al. (2015) have studied students' academic self-concept in relation to their academic achievement. To this aim, two questionnaires were distributed among 407 college students. Inspecting the correlation of questionnaires, the researchers found that college students' academic self-concept is closely related to their academic achievement. Similarly, Colmar et al. (2019) have delved into the role of students' self-concept in improving their academic performance. In doing so, 191 students were asked to express their viewpoints by completing two valid questionnaires. They perceived student self-concept to be a favorable predictor of academic performance. In another study, Amiryousefi and Mirkhani (2019) have inspected the role of students' academic self-concept in their willingness to communicate. To this aim, the questionnaires of willingness to communicate and academic self-concept were given to 136 Iranian students. The analysis of students' viewpoints indicated that students' willingness to communicate can be remarkably predicted by their academic self-concept.

\section{The Impact of Positive Mood and Future Outlook on EFL Students' Academic Self-Concept}

Drawing on positive psychology principles, Dewaele et al. (2019) asserted that the positive mental states that EFL students experience in English language classes may favorably affect their academic behaviors, including academic self-concept. Consistent with Dewaele et al. (2019) assertion, Li et al. (2020) also maintained that students' positive moods caused by teachers, classmates, or the learning environment can positively influence their academic behaviors. Regarding the impact of future outlook on EFL students' self-concept, Wang et al. (2021) stated that being optimistic about the future may have a positive impact on EFL students' academic self-concept. That is, those EFL students who have positive beliefs and expectations about their academic future are able to improve their academic self-concept.

\section{CONCLUSION AND PEDAGOGICAL IMPLICATIONS}

So far, different definitions and conceptualizations of positive mood, future outlook, and student academic self-concept were offered. Relying on positive psychology principles, the favorable effects of positive mood and future outlook on EFL students' academic self-concept were also illustrated. With regard to the theoretical evidence, one can fairly conclude that EFL students' academic self-concept can be remarkably influenced by both positive mood and future outlook. This finding appears to be informative and instructive for EFL teachers in any educational environment. Given the importance of positive moods and emotions in improving students' academic self-concept (Dewaele et al., 2019; Wang et al., 2021), teachers who are in charge of enhancing students' academic behaviors should provide students with an enjoyable learning atmosphere in order to instill positive feelings in their minds. Moreover, as positive teacher interpersonal behaviors will result in students positive state of mind (Xie and Derakhshan, 2021), teachers are expected to make use of effective interpersonal behaviors in interactions with their pupils. The finding of this review seems to be illuminative for EFL students as well. As the findings of this review indicated, students' beliefs and attitudes about their future can largely influence their academic self-concept. Students are thus required to be optimistic about their future in order to improve their academic self-concept. Given the paucity of research on positive mood, future outlook, and their interrelationships with EFL students' academic selfconcept, future investigations on this topic are thus recommended.

\section{AUTHOR CONTRIBUTIONS}

The author confirms being the sole contributor of this work and has approved it for publication. 


\section{REFERENCES}

Akbari Chermahini, S., and Hommel, B. (2012). More creative through positive mood? Not everyone. Front. Hum. Neurosci. 6:319. doi: 10.3389/ fnhum.2012.00319

Amiryousefi, M., and Mirkhani, M. (2019). Interrelationships between willingness to communicate, self-concept, ideal L2 self, and teacher credibility among Persian language learners in Iran. J. Teach. Persian Speak. Other Lang. 8, 51-68. doi: 10.30479/JTPSOL.2019.9593.1409

Asadzadeh Maleki, N., Zoghi, M., and Asadi, N. (2021). A structural equation model of the impact of teacher-student interaction and academic self-concept on EFL learners' academic achievement. J. Lang. Horizon. doi: 10.22051/ LGHOR.2021.34581.1426

Biyikl, C. (2021). The relationship between language learning strategies and academic self-concept. Int. J. Progress. Educ. 17, 101-123. doi: 10.29329/ ijpe.2020.332.7

Brand, S., Reimer, T., and Opwis, K. (2007). How do we learn in a negative mood? Effects of a negative mood on transfer and learning. Learn. Instr. 17, 1-16. doi: 10.1016/j.learninstruc.2006.11.002

Chao, C. N. G., McInerney, D. M., and Bai, B. (2019). Self-efficacy and self-concept as predictors of language learning achievements in an Asian bilingual context. Asia Pac. Educ. Res. 28, 139-147. doi: 10.1007/ s40299-018-0420-3

Chen, B. H., Chiu, W. C., and Wang, C. C. (2015). The relationship among academic self-concept, learning strategies, and academic achievement: a case study of national vocational college students in Taiwan via SEM. Asia-Pac Educ. Res. 24, 419-431. doi: 10.1007/s40299-014-0194-1

Cianci, A. M., and Bierstaker, J. L. (2009). The impact of positive and negative mood on the hypothesis generation and ethical judgments of auditors. Audit. J. Pract. Theor. 28, 119-144. doi: 10.2308/aud.2009.28.2.119

Colmar, S., Liem, G. A. D., Connor, J., and Martin, A. J. (2019). Exploring the relationships between academic buoyancy, academic self-concept, and academic performance: a study of mathematics and reading among primary school students. Educ. Psychol. 39, 1068-1089. doi: 10.1080/01443410.2019.1617409

Cooper, K. M., Krieg, A., and Brownell, S. E. (2018). Who perceives they are smarter? Exploring the influence of student characteristics on student academic self-concept in physiology. Adv. Physiol. Educ. 42, 200-208. doi: 10.1152/ advan.00085.2017

Curtin, N., Stewart, A. J., and Ostrove, J. M. (2013). Fostering academic selfconcept: advisor support and sense of belonging among international and domestic graduate students. Am. Educ. Res. J. 50, 108-137. doi: $10.3102 / 0002831212446662$

De Fraine, B., Van Damme, J., and Onghena, P. (2007). A longitudinal analysis of gender differences in academic self-concept and language achievement: a multivariate multilevel latent growth approach. Contemp. Educ. Psychol. 32, 132-150. doi: 10.1016/j.cedpsych.2006.10.005

Dewaele, J. M., Chen, X., Padilla, A. M., and Lake, J. (2019). The flowering of positive psychology in foreign language teaching and acquisition research. Front. Psychol. 10:2128. doi: 10.3389/fpsyg.2019.02128

Djamasbi, S., Fruhling, A., and Loiacono, E. (2009). The influence of affect, attitude and usefulness in the acceptance of telemedicine systems. J. Inform. Technol. Theor. Appl. 10, 41-58.

Djamasbi, S., Strong, D. M., and Dishaw, M. (2010). Affect and acceptance: examining the effects of positive mood on the technology acceptance model. Decis. Support. Syst. 48, 383-394. doi: 10.1016/j.dss.2009.10.002

Dörnyei, Z. (2009). "The L2 motivational self-system," in Motivation, Language Identity and the L2 Self. eds. Z. Dörnyei and E. Ushioda (Bristol: Multilingual Matters), 9-42.

Drew, P. Y., and Watkins, D. (1997). Affective variables, learning approaches and academic achievement: a casual modelling investigation with Hong Kong tertiary students. Br. J. Educ. Psychol. 68, 173-188.

Eccles, J. S. (1983). "Expectancies, values, and academic behaviors," in Achievement and Achievement Motivation: Psychological and Sociological Approaches. ed. J. T. Spence (San Francisco, CA: W.H. Freeman), 75-146.

Eccles, J. S., and Wigfield, A. (1995). In the mind of the actor: the structure of adolescents' achievement task values and expectancy-related beliefs. Personal. Soc. Psychol. Bull. 21, 215-225. doi: 10.1177/0146167295213003
Ehm, J. H., Hasselhorn, M., and Schmiedek, F. (2019). Analyzing the developmental relation of academic self-concept and achievement in elementary school children: alternative models point to different results. Dev. Psychol. 55, 2336-2351. doi: $10.1037 /$ dev0000796

Emmanuel, A. O., Adom, E. A., Josephine, B., and Solomon, F. K. (2014). Achievement motivation, academic self-concept and academic achievement among high school students. Eur. J. Res. Refl. Educ. Sci. 2, 24-37.

Erten, İ. H., and Burden, R. L. (2014). The relationship between academic self-concept, attributions, and L2 achievement. System 42, 391-401. doi: 10.1016/j.system.2014.01.006

Febrilia, I., and Warokka, A. (2014). "The effects of positive and negative mood on university students' learning and academic performance: evidence from Indonesia." in The 3rd International Conference on Humanities and Social Sciences; April 2, 2011.

Fiedler, K., Nickel, S., Asbeck, J., and Pagel, U. (2003). Mood and the generation effect. Cognit. Emot. 17, 585-608. doi: 10.1080/02699930302301

Franklin, A. S., Debb, S. M., and Colson, D. G. (2017). Predictors of academic self-concept for African American college students. J. Black Psychol. 43, 636-653. doi: 10.1177/0095798416671578

Fredrickson, B. L. (2003). "Positive emotions and upward spirals in organizations," in Positive Organizational Scholarship. eds. K. S. Cameron, J. E. Dutton and R. E. Quinn (San Francisco: Berret-Koehler Publishers), 163-175.

Grol, M., and Raedt, R. D. (2014). Effects of positive mood on attentional breadth for emotional stimuli. Front. Psychol. 5:1277. doi: 10.3389/ fpsyg.2014.01277

Haktanir, A., Watson, J. C., Ermis-Demirtas, H., Karaman, M. A., Freeman, P. D., Kumaran, A., et al. (2021). Resilience, academic self-concept, and college adjustment among first-year students. J. Clg. Stud. Reten. Res. Theor. Pract. 23, 161-178. doi: 10.1177/1521025118810666

Holman, D., and Niven, K. (2019). Does interpersonal affect regulation influence others' task performance? The mediating role of positive mood. Eur. J. Work Organ. Psy. 28, 820-830. doi: 10.1080/1359432X.2019.1666105

Huang, C. (2011). Self-concept and academic achievement: a meta-analysis of longitudinal relations. J. Sch. Psychol. 49, 505-528. doi: 10.1016/j.jsp.2011.07.001

Isen, A. M. (2008). "Some ways in which positive affect influences decision making and problem solving," in Handbook of Emotions. ed. M. Lewis (New York, NY: Guilford Press), 548-573.

Jeon, J. O. (1990). An empirical investigation of the relationship between affective states, in-store browsing, and impulse buying. doctoral dissertation. University of Alabama.

Kim, Y. K., and Sax, L. J. (2014). The effects of student-faculty interaction on academic self-concept: does academic major matter? Res. High. Educ. 55, 780-809. doi: 10.1007/s11162-014-9335-x

Kulakow, S. (2020). Academic self-concept and achievement motivation among adolescent students in different learning environments: does competencesupport matter. Learn. Motiv. 70:101632. doi: 10.1016/j.lmot.2020.101632

Li, C., Dewaele, J. M., and Jiang, G. (2020). The complex relationship between classroom emotions and EFL achievement in China. Appl. Ling. Rev. 11, 485-510. doi: 10.1515/applirev-2018-0043

Lohbeck, A., Grube, D., and Moschner, B. (2017). Academic self-concept and causal attributions for success and failure amongst elementary school children. Int. J. Early Years Educ. 25, 190-203. doi: 10.1080/09669760.2017.1301806

Lount, R. B. (2010). The impact of positive mood on trust in interpersonal and intergroup interactions. J. Pers. Soc. Psychol. 98, 420-433. doi: 10.1037/ a0017344

Ma, L., Luo, H., and Xiao, L. (2021). Perceived teacher support, self-concept, enjoyment and achievement in reading: a multilevel mediation model based on PISA 2018. Learn. Individ. Differ. 85:101947. doi: 10.1016/j.lindif.2020.101947

Mackie, D. M., and Worth, L. T. (2020). "Feeling good, but not thinking straight: the impact of positive mood on persuasion," in Emotion and Social Judgments. ed. J. P. Forgas (New York, NY: Garland Science), 201-219.

Marsh, H. W., and Martin, A. J. (2011). Academic self-concept and academic achievement: relationships and causal ordering. Br. J. Educ. Psychol. 81, 59-77. doi: 10.1348/000709910X503501

McFarland, L., Murray, E., and Phillipson, S. (2016). Student-teacher relationships and student self-concept: relations with teacher and student gender. Aust. J. Educ. 60, 5-25. doi: 10.1177/0004944115626426 
McInerney, D. M., Cheng, R. W. Y., Mok, M. M. C., and Lam, A. K. H. (2012). Academic self-concept and learning strategies: direction of effect on student academic achievement. J. Adv. Acad. 23, 249-269. doi: $10.1177 / 1932202 \mathrm{X} 12451020$

Mercer, S. (2009). "The dynamic nature of a tertiary learner's foreign language self-concepts," in New Perspectives on Individual Differences in Language Learning and Teaching. ed. M. Pawlak (Poland: Adam Mickiewicz University Press), 205-220.

Mercer, S. (2011). Language learner self-concept: complexity, continuity and change. System 39, 335-346. doi: 10.1016/j.system.2011.07.006

Möller, J., Zitzmann, S., Helm, F., Machts, N., and Wolff, F. (2020). A metaanalysis of relations between achievement and self-concept. Rev. Educ. Res. 90, 376-419. doi: 10.3102/0034654320919354

Nuttin, J. (2014). Future Time Perspective and Motivation: Theory and Research Method. New York, NY: Psychology Press.

Pax, J. A. (2020). Young adult future outlook in the context of parent advice, parent-young adult closeness, and young adult ability self-concept. doctoral dissertation. Montclair State University, New Jersey.

Prince, D., and Nurius, P. S. (2014). The role of positive academic self-concept in promoting school success. Child Youth Serv. Rev. 43, 145-152. doi: 10.1016/j.childyouth.2014.05.003

Schoon, I. (2012). Planning for the future in times of social change. Child Dev. Perspect. 6, 335-341. doi: 10.1111/cdep.12003

Schoon, I., and Mortimer, J. (2017). Youth and the great recession: are values, achievement orientation and outlook to the future affected. Int. J. Psychol. 52, 1-8. doi: 10.1002/ijop.12400

Seaton, M., Parker, P., Marsh, H. W., Craven, R. G., and Yeung, A. S. (2014). The reciprocal relations between self-concept, motivation and achievement: juxtaposing academic self-concept and achievement goal orientations for mathematics success. Educ. Psychol. 34, 49-72. doi: 10.1080/01443410.2013.825232

Seginer, R. (2009). Future Orientation: Developmental and Ecological Perspectives. New York, NY: Springer Publications.

Shane, J., and Heckhausen, J. (2016). It's only a dream if you wake up: young adults' achievement expectations, opportunities, and meritocratic beliefs. Int. J. Psychol. 52, 40-48. doi: 10.1002/ijop.12408

Trautwein, U., and Möller, J. (2016). "Self-concept: determinants and consequences of academic self-concept in school contexts," in Psychosocial Skills and School Systems in the 21st Century. eds. A. A. Lipnevich, F. Preckel and R. D. Roberts (Cham: Springer), 187-214.

Venkatesh, V., and Speier, C. (1999). Computer technology training in the workplace: a longitudinal investigation of the effect of mood. Organ. Behav. Hum. Decis. Process. 79, 1-28. doi: 10.1006/obhd.1999.2837

Wang, Y., Derakhshan, A., and Zhang, L. J. (2021). Researching and practicing positive psychology in second/foreign language learning and teaching: the past, current status and future directions. Front. Psychol. 12:731721. doi: 10.3389/fpsyg.2021.731721

Wang, Y. L., and Guan, H. F. (2020). Exploring demotivation factors of Chinese learners of English as a foreign language based on positive psychology. Rev. Argent. Clin. Psicol. 29, 851-861. doi: 10.24205/03276716.2020.116

Weiner, B. (2010). The development of an attribution-based theory of motivation: a history of ideas. Educ. Psychol. 45, 28-36. doi: $10.1080 / 00461520903433596$

Wigfield, A., and Eccles, J. S. (2001). Expectancy-value theory of achievement motivation. Contemp. Educ. Psychol. 25, 68-81. doi: 10.1006/ceps.1999.1015

Wigfield, A., Rosenzweig, E., and Eccles, J. (2017). "Achievement values," in Handbook of Competence and Motivation: Theory and Application. eds. A. J. Elliot, C. S. Dweck and D. S. Yeager (New York, NY: Guilford Press), 116-134.

Wolff, F., Helm, F., Zimmermann, F., Nagy, G., and Möller, J. (2018). On the effects of social, temporal, and dimensional comparisons on academic selfconcept. J. Educ. Psychol. 110, 1005-1025. doi: 10.1037/edu0000248

Xie, F., and Derakhshan, A. (2021). A conceptual review of positive teacher interpersonal communication behaviors in the instructional context. Front. Psychol. 12:708490. doi: 10.3389/fpsyg.2021.708490

Yeboah, A., Dogbey, J., and Yuan, G. (2018). Exploring factors that promote online learning experiences and academic self-concept of minority high school students. J. Res. Technol. Educ. 50, 1-17. doi: 10.1080/15391523. 2017.1365669

Zhang, D., Cui, Y., Zhou, Y., Cai, M., and Liu, H. (2018). The role of school adaptation and self-concept in influencing Chinese high school students' growth in math achievement. Front. Psychol. 9:2356. doi: 10.3389/ fpsyg.2018.02356

Conflict of Interest: The author declares that the research was conducted in the absence of any commercial or financial relationships that could be construed as a potential conflict of interest.

Publisher's Note: All claims expressed in this article are solely those of the authors and do not necessarily represent those of their affiliated organizations, or those of the publisher, the editors and the reviewers. Any product that may be evaluated in this article, or claim that may be made by its manufacturer, is not guaranteed or endorsed by the publisher.

Copyright (c) 2022 Zhang. This is an open-access article distributed under the terms of the Creative Commons Attribution License (CC BY). The use, distribution or reproduction in other forums is permitted, provided the original author(s) and the copyright owner(s) are credited and that the original publication in this journal is cited, in accordance with accepted academic practice. No use, distribution or reproduction is permitted which does not comply with these terms. 